\title{
Unilateral control of ovarian oxytocin release and the facilitatory effects of insulin-like growth factor-I in sheep
}

\author{
I. R. Fleet ${ }^{1}$, A. J. Davis ${ }^{1}$, J. A. Goode ${ }^{1}$, M. Hamon ${ }^{1}$, \\ R. J. Collier ${ }^{2}$ and R. B. Heap ${ }^{1 *}$ \\ ${ }^{I}$ The Babraham Institute, Babraham, Cambridge CB2 4AT, UK; and ${ }^{2}$ Monsanto Company, \\ 700 Chesterfield Village Parkway, Chesterfield, St Louis, MO 63198, USA
}

\begin{abstract}
Prostaglandin $\mathrm{F}_{2 \alpha}\left(\mathrm{PGF}_{2 \alpha}\right)$-induced release of ovarian oxytocin was investigated to determine whether the effect in vivo was local. $\left[{ }^{3} \mathrm{H}\right] \mathrm{PGF}_{2 \alpha}$ infused downstream into a single ovarian lymphatic was transferred into the adjacent ovarian vasculature (estimated transfer 1.1 and $1.7 \%$, two experiments). When unlabelled PGF $_{2 \alpha}$ was infused in a similar manner $\left(76 \mathrm{pmol} \mathrm{min}^{-1}\right)$, there was a prompt eightfold increase in ovarian oxytocin release from the adjacent ovary containing a corpus luteum, but no effect on the opposite corpus luteum, showing that the effect was local. Instillation of $2 \%$ lignocaine into the ovarian vascular pedicle did not affect $\mathrm{PGF}_{2 \alpha}$-induced oxytocin release, supporting the idea that neural mechanisms are not involved. Repeated doses of $\mathrm{PGF}_{2 \alpha}$ given close-arterially produced a successive reduction in oxytocin release. This effect was prevented by a prior infusion of insulin-like growth factor-I (IGF-I), which itself gave a small, but significant, increase in oxytocin release. The results show that $\mathrm{PGF}_{2 \alpha}$ in ovarian lymphatics acts locally and directly to stimulate ovarian oxytocin secretion, that repeated exposure of the corpus luteum to pulses of $\mathrm{PGF}_{2 \alpha}$ can result in tachyphylaxis, and that this latter effect can be ameliorated by IGF-I infused in vivo.
\end{abstract}

Introduction

The ability of prostaglandin $\mathrm{F}_{2 \alpha}\left(\mathrm{PGF}_{2 \alpha}\right)$ to stimulate in vivo the release of oxytocin by the corpus luteum in sheep (Flint and Sheldrick, 1982; Sheldrick and Flint, 1983) and cattle (Schallenberger et al., 1984) is well established (Wathes and Denning Kendall, 1992 for review). Other compounds that produce a similar effect include the neurotransmitters acetylcholine and noradrenaline in sheep (Heap et al., 1989) and noradrenaline in cattle (Kotwica et al., 1991). Demonstration of a direct effect of $\mathrm{PGF}_{2 \alpha}$ in vitro has been more difficult (Hirst et al., 1986, 1988; Wathes et al., 1988; McArdle and Holtorf, 1989), although some studies have reported a dose-response effect with luteal slices at day 8 of the cycle. Release has also been inferred from cultured luteal cells (Abdelgadir et al., 1987; Jarry et al., 1992). The present study examines whether other mechanisms are involved in vivo, since our previous work showed that $\mathrm{PGF}_{2 \alpha}$ infused into a uterine lymphatic caused a rapid bilateral release of ovarian oxytocin. This result indicated that $\mathrm{PGF}_{2 \alpha}$ may act indirectly rather than directly on the corpus luteum (Heap et al., 1989).

${ }^{*}$ Correspondence.

Revised manuscript received 24 August 1993.
Materials and Methods

Animals

Multiparous non-pregnant ewes were obtained from the Institute's flocks of Clun Forest and Friesland sheep. The time of ovulation was regulated by the i.m. injection of $\mathrm{PGF}_{2 \alpha}$ analogue (cloprostenol: ICI Pharmaceuticals, Alderley Edge, Cheshire) using the technique referred to by Heap et al. (1985). Animals were superovulated (number of corpora lutea, $4.5 \pm 0.7$, mean \pm SEM) by the i.m. injection of 800 iu serum gonadotrophin (Folligon: Intervet Laboratories Ltd, Cambridge) 8 days after the first injection of cloprostenol (Estrumate: Coopers Animal Health, Crewe, Cheshire). The sheep were kept in paddocks adjacent to the laboratory and housed on the day before an experiment. All experiments were carried out at day I0 after ovulation.

\section{Experimental methods}

Unilateral transfer. Previous studies showed that $\mathrm{PGF}_{2 \alpha}$ infused into a uterine lymphatic caused a rapid bilateral release of ovarian oxytocin (Heap et al., 1989). To test whether this was due to the local stimulation of nerves in the vascular 
pedicle, or to the transfer of $\mathrm{PGF}_{2 \alpha}$ across the broad ligament through the utero-ovarian lymphatic network, $\mathrm{PGF}_{2 \alpha}$ was infused into a single ovarian lymphatic which restricted its distribution unilaterally. Evidence for local transfer from an ovarian lymphatic into the adjacent ovary was gained using a modification of the technique described by Heap et al. (1985). Under pentobarbitone (RMB Animal Health Ltd, Dagenham) anaesthesia ( $20 \mathrm{ml} 60 \mathrm{mg} \mathrm{ml}^{-1}$, i.v.) a single ovarian lymphatic was exposed close to the hilus of the ovary and a polyvinyl catheter $(0.5 \mathrm{~mm}$ i.d., $0.8 \mathrm{~mm}$ o.d.; Dural Plastics, Dural, NSW) inserted downstream. [9- $\left.{ }^{3} \mathrm{H}\right]$ Prostaglandin $\mathrm{F}_{2 \alpha}$ (specific activity $14.8 \mathrm{Ci} \mathrm{mmol}^{-1}$ ), D-[1- ${ }^{14} \mathrm{C}$ mannitol (specific activity $55 \mathrm{mCi} \mathrm{mmol}^{-1}$, marker of paracellular transfer) and ${ }^{36} \mathrm{Cl}$ (sodium chloride solution, $\left[{ }^{36} \mathrm{Cl}\right] \mathrm{Na}$; $>3 \mathrm{mCi} \mathrm{Cl} \mathrm{g}^{-1}$, marker of rapid diffusion) obtained from Amersham International (Amersham, Bucks) were diluted in $0.9 \%(\mathrm{w} / \mathrm{v}) \mathrm{NaCl}$ and kept frozen at $-10^{\circ} \mathrm{C}$ until required (approximate concentrations for $\left[{ }^{3} \mathrm{H}\right] \mathrm{PGF}_{2 \alpha^{\prime}}\left[{ }^{14} \mathrm{C}\right]$ mannitol and $\left[{ }^{36} \mathrm{Cl}\right] \mathrm{Na}, 9,4$ and $\left.4 \mu \mathrm{Ci} \mathrm{ml}{ }^{-1}\right)$. Simultaneous infusion $\left(4.1 \mathrm{ml} \mathrm{h}^{-1}\right)$ of all three compounds lasted for $60 \mathrm{~min}$ and blood samples from catheters placed in an ovarian vein, utero-ovarian vein and carotid artery were collected simultaneously at $5 \mathrm{~min}$ intervals for $120 \mathrm{~min}$ after the start of the infusion. Ovarian vein rather than ovarian arterial blood was collected to avoid any disturbance of ovarian haemodynamics.

Unilateral release. The effect of $\mathrm{PGF}_{2 \alpha}$ on ovarian oxytocin release was assessed by the unilateral infusion of unlabelled $\mathrm{PGF}_{2 \alpha}\left(76 \mathrm{pmol} \mathrm{min}{ }^{-1}\right.$ for $\left.10 \mathrm{~min}, 4.1 \mathrm{ml} \mathrm{h}^{-1}\right)$ into an ovarian lymphatic. Blood samples were collected simultaneously at 2.5 , 5 and 10 min after the start of the infusion from right and left ovarian veins $(1 \mathrm{ml}$ each) and a carotid artery $(5 \mathrm{ml})$. Other details relating to sampling and measurement of radioactivity were as reported by Heap et al. (1989).

Ovarian infusion. Acetylcholine $\left(5 \mu \mathrm{mol} \mathrm{1}^{-1}\right), \quad \mathrm{PGF}_{2 \alpha}$ $\left(28 \mathrm{pmol} \mathrm{min}^{-1}\right)$ and recombinant insulin-like growth factor I (7.5 nmol IGF-I min $^{-1}$, batch no. GTS-2; Monsanto Company, St Louis, MO) were injected (acetylcholine) or infused closearterially $\left(\mathrm{PGF}_{2 \alpha^{\prime}}\right.$ IGF-I) through an indwelling polythene catheter ( $1.0 \mathrm{~mm}$ i.d., $1.5 \mathrm{~mm}$ o.d.) introduced into a femoral artery and advanced in a retrograde direction to lie cranial to the origin of the ovarian arteries (about $25 \mathrm{~cm}$ from insertion). The end of the catheter was blocked and fine holes were pierced at the end to ensure thorough mixing of injectate into arterial blood. The position of the catheter was confirmed by the infusion of Evans blue ( $1 \%$ in saline) with repeated sampling from the ovarian vein catheters. Analysis of Evans blue in blood of the ovarian vein showed that the mean dilution factor was $382 \pm 79(n=15$; Heap et al., 1989). During test periods, blood samples were collected simultaneously from the ovarian vein $(1 \mathrm{ml})$ and carotid artery $(5 \mathrm{ml})$ at 2.5 , 5 and $10 \mathrm{~min}$ after the start of the infusion, and during control periods at 10,20 and $30 \mathrm{~min}$ after the end of the test period. Blood pressure and heart rate were recorded continuously using a pressure transducer (Transamerican Instruments, Basingstoke, Hants) connected to the carotid arterial catheter.
Assay. Oxytocin was measured using the assay described and validated by Sheldrick and Flint (1983).

Statistical analysis. For unilateral transfer studies, venoarterial differences were calculated from the plasma concentration of radiolabelled compounds in the ovarian or utero-ovarian vein minus that in the carotid artery. Each value was plotted against time after the start of the infusion, and the area under the curve determined as described by Heap et al. (1985). For the release of endogenous oxytocin, a mean value of three samples collected during the $10 \mathrm{~min}$ infusion was calculated for each treatment, uncorrected for the carotid arterial value which was $<30 \mathrm{pg} \mathrm{ml}^{-1}$. All endogenous values were transformed to the natural logarithm and the experimental results compared with control values by Student's $t$ test.

\section{Results}

Ovarian lymphatic infusion of $P G F_{2 a}$

Transfer of $P G F_{2 a} . \quad\left[{ }^{3} \mathrm{H}\right] \mathrm{PGF}_{2 \alpha^{\prime}}\left[{ }^{14} \mathrm{C}\right]$ mannitol and $\left[{ }^{36} \mathrm{Cl}\right]$ were all transferred from an ovarian lymphatic into the ipsilateral utero-ovarian vein and ovary (as shown by ovarian vein

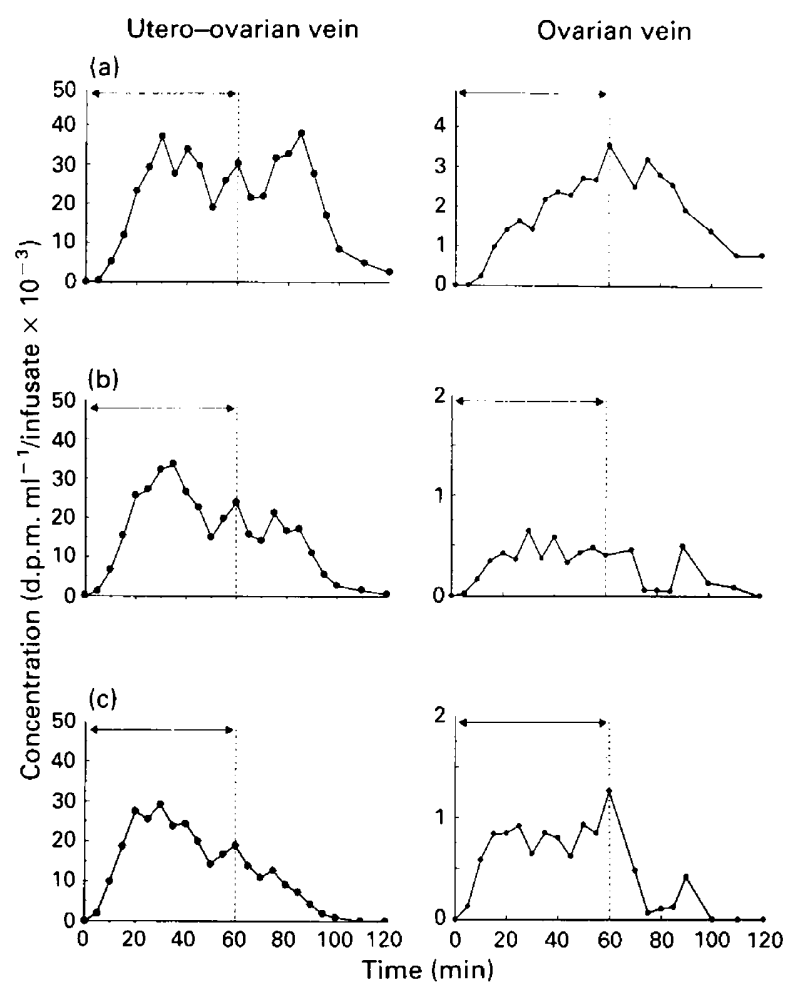

Fig. 1. Kinetics of transfer of (a) $\left[{ }^{3} \mathrm{H}\right] \mathrm{PGF}_{2 \alpha}$ (b) $\left[{ }^{14} \mathrm{C}\right]$ mannitol and (c) $\left[{ }^{36} \mathrm{Cl}\right] \mathrm{Na}$ from a single ovarian lymphatic into the adjacent uteroovarian vein and ovarian vein in a sheep 10 days after oestrus. Veno-arterial differences (utero-ovarian vein minus carotid artery, ovarian vein minus carotid artery) were calculated for blood samples collected during and after a $\mathrm{I}$ h infusion which was given downstream into an ovarian lymphatic. Ovarian vein values were obtained from blood collected at its origin from the ovary. 
Table 1. Ovarian oxytocin release (mean \pm SEM) induced by $\mathrm{PGF}_{2 \alpha}\left(76 \mathrm{pmol} \mathrm{min}^{-1}\right.$ for $10 \mathrm{~min}$ ) infused unilaterally into an ovarian lymphatic

\begin{tabular}{|c|c|c|c|}
\hline \multirow[b]{2}{*}{ Treatment sequence } & \multicolumn{2}{|c|}{ Oxytocin concentration (pg ml ${ }^{-1}$ ) } & \multirow{2}{*}{$\begin{array}{c}\text { Fold-change } \\
\text { (compared with control } 1 \text { ) }\end{array}$} \\
\hline & Back-transformed & $\log _{e}$ & \\
\hline \multicolumn{4}{|c|}{ Ipsilateral corpus luteum $(n=5)$} \\
\hline Control 1 & 645 & $6.47 \pm 0.37$ & 1.0 \\
\hline $\mathrm{PGF}_{2 \alpha}$ & 5379 & $8.59 \pm 0.55^{*}$ & 8.3 \\
\hline Control 2 & 1153 & $7.05 \pm 0.38$ & 1.8 \\
\hline Acetylcholine (i.a.) ${ }^{\mathbf{a}}$ & 2298 & $7.74 \pm 0.46$ & 3.6 \\
\hline \multicolumn{4}{|c|}{ Contralateral corpus luteum $(n=3)$} \\
\hline Control 1 & 735 & $6.60 \pm 0.42$ & 1.0 \\
\hline $\mathrm{PGF}_{2 \alpha}$ & 620 & $6.43 \pm 0.23$ & 0.8 \\
\hline Control 2 & 773 & $6.65 \pm 0.79$ & 1.1 \\
\hline Acetylcholine (i.a.) & 3498 & $8.16 \pm 0.77$ & 4.8 \\
\hline
\end{tabular}

Results show mean concentration during infusion period in superovulated non-pregnant sheep.

${ }^{a}$ Acetylcholine $(5 \mu \mathrm{mol})$ was given as a single injection via a catheter placed cranial to the origin of the ovarian arteries. Statistical . analysis of transformed data by paired $t$ test comparing each treatment with the previous control value $\left({ }^{*} P<0.05\right)$.

Table 2. Ovarian oxytocin release (mean \pm SEM) after repeated close-arterial infusions of prostaglandin $\mathrm{F}_{2 \alpha}$ $\left(28 \mathrm{pmol} \mathrm{min}{ }^{-1}\right.$ for $10 \mathrm{~min}$ ) via a catheter placed cranial to the origin of the ovarian arteries

\begin{tabular}{lccc}
\hline & \multicolumn{2}{c}{ Oxytocin concentration $\left(\mathrm{pg} \mathrm{ml}^{-1}\right)$} & $\begin{array}{c}\text { Fold-change } \\
\text { Treatment sequence }\end{array}$ \\
\cline { 2 - 3 } & Back-transformed & $\log _{e}$ & (compared to control 1) \\
\hline Control I & 748 & $6.62 \pm 0.55$ & 1.0 \\
PGF $_{2 \alpha}$ first infusion & 11304 & $9.33 \pm 0.31^{* *}$ & 15.1 \\
Control 2 & 724 & $6.59 \pm 0.42$ & 0.9 \\
PGF $_{2 \alpha}$ second infusion & 5054 & $8.53 \pm 0.15^{*}$ & 6.8 \\
Control 3 $_{\text {PGF }}$ & 621 & $6.43 \pm 0.42$ & 0.8 \\
& 3425 & $8.14 \pm 0.41$ & 4.6 \\
\hline
\end{tabular}

Results show mean concentration during infusion period in superovulated non-pregnant sheep $(n=4)$.

Statistical analysis of transformed data by paired $t$ test comparing each treatment with the previous control value $\left({ }^{*} P<0.05\right.$, $\left.{ }^{* *} P<0.01\right)$.

values). Transfer of $\mathrm{PGF}_{2 \alpha}$ into the ovary increased linearly over the $60 \mathrm{~min}$ infusion and declined steadily when the infusion ceased $\left(t_{0.5}=19 \mathrm{~min}\right)$. In contrast, mannitol and chloride reached a plateau after infusion for about $30 \mathrm{~min}$ (Fig. 1). In two sheep, the estimated transfer into ovarian blood was 1.7 and $1.1 \%$ for PGF $_{2 \alpha^{\prime}} 0.7$ and $0.6 \%$ for mannitol and 1.2 and $0.9 \%$ for $\mathrm{NaCl}$. Transfer of the three labelled compounds into the utero-ovarian vein was 47.2 and $22.6,85$ and 43 , and 75 and $48 \%$, respectively.

Oxytocin release. To determine whether locally transferred $\mathrm{PGF}_{2 \alpha}$ stimulated ovarian oxytocin release, unlabelled $\mathrm{PGF}_{2 \alpha}$ was infused into a single ovarian lymphatic. This produced an eightfold increase in oxytocin release from the ipsilateral ovary. There was no change in oxytocin release from the contralateral ovary in animals with bilateral corpora lutea demonstrating that the effect was local. A subsequent injection of acetylcholine (intra-arterial) gave a bilateral release of oxytocin which increased by three- to fourfold indicating that corpora lutea in both ovaries contained oxytocin (Table I).

Repeated arterial infusion of $P G F_{2 a}$. To investigate whether repeated administration caused a diminishing oxytocin response, a close-arterial infusion of $\mathrm{PGF}_{2 \alpha}$ was given for $10 \mathrm{~min}$ through a catheter positioned cranial to the origin of the ovarian arteries. The infusion was repeated at intervals of approximately $30 \mathrm{~min}$ and produced a declining response on three successive occasions (15.1, 6.8 and 4.6-fold increase in release). During the third infusion, the 4.6 -fold increase was not significantly greater than that of the preceding control period (Table 2). Similar results were obtained when the experiment was repeated in four sheep with bilateral corpora lutea; the third infusion was replaced by a single injection of acetylcholine ( $5 \mu \mathrm{mol}$; data not shown). Instillation of $2 \%$ lignocaine into the ovarian vascular pedicle after the first infusion failed to affect the results obtained. 


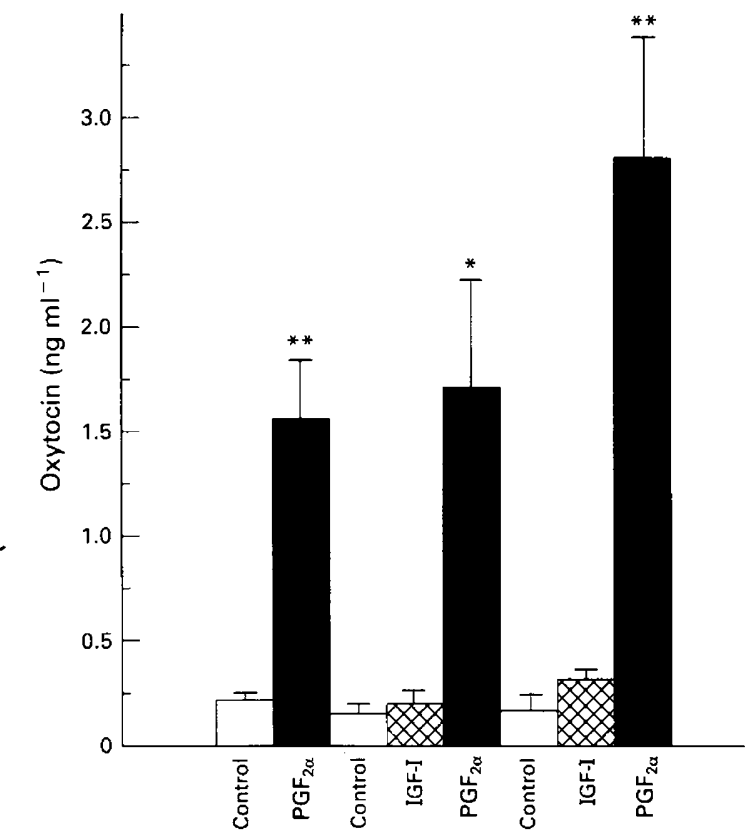

Fig. 2. Effect of insulin-like growth factor-I (IGF-I, $7.5 \mathrm{nmol} \mathrm{min}{ }^{-1}$ for $10 \mathrm{~min})$ on ovarian oxytocin release induced by $\mathrm{PGF}_{2 \alpha}\left(28 \mathrm{pmol} \mathrm{min}^{-1}\right.$ for $10 \mathrm{~min}$ ). Infusions of saline (control), $\mathrm{PGF}_{2 \alpha}$ and IGF-I were given sequentially and close-arterially via a catheter placed cranial to the origin of the ovarian arteries in a superovulated anaesthetized sheep. Blood was collected from the ovarian vein of an ovary containing two corpora lutea for measurement of oxytocin. Statistical significance of oxytocin concentrations $\left(\log _{\mathrm{e}}\right)$ after treatment compared with preceding control value $\left({ }^{*} P<0.05 ;{ }^{* *} P<0.01\right)$.

Effect of IGF-I on repeated PGF $2 a^{-i n d u c e d ~ r e l e a s e ~ o f ~ o x y t o c i n . ~}$ To test whether IGF-I influenced the release of ovarian oxytocin, the peptide was infused for $10 \mathrm{~min}$ after the first and second infusions of $\mathrm{PGF}_{2 \alpha}$. Increased release of oxytocin occurred in three of five sheep at the first infusion of IGF-I, and in all five animals at the second. Thereafter, a third infusion of $\mathrm{PGF}_{2 \alpha}$ produced a significant increase in oxytocin release $(P<0.01$, Fig. 2, Table 3).

\section{Discussion}

Downstream infusion of $\mathrm{PGF}_{2 \alpha}$ into a single ovarian lymphatic caused a significant release of oxytocin from the adjacent, but not from the opposite, ovary. The increased release corresponded to the time when the transfer of radiolabelled $\mathrm{PGF}_{2 \alpha}$ infused into an ovarian lymphatic was first detected in ovarian blood. The estimated amount of $\mathrm{PGF}_{2 \alpha}$ transferred into the adjacent ovary $(1.4 \%)$ was greater than that obtained in our previous studies for the transfer from a uterine lymphatic $(0.4 \%)$. The kinetics of transfer of the paracellular marker, mannitol, and the rapid diffusion marker, sodium chloride, which reached peak concentrations in the ovarian vein within $30 \mathrm{~min}$, corroborated our earlier conclusion that $\mathrm{PGF}_{2 \alpha}$ is probably transferred by the slower process of facilitated diffusion (Heap et al., 1989). Thus the countercurrent transfer of $\mathrm{PGF}_{2 \alpha}$ into the ovary from an adjacent ovarian (or uterine) lymphatic provided the local stimulus for oxytocin release.

Failure of an intra-ovarian lymphatic infusion of $\mathrm{PGF}_{2 \alpha}$ to release oxytocin from the opposite ovary contrasts with our earlier result when an intrauterine lymphatic produced a bilateral response (Heap et al., 1989). Cross-connections between uterine lymphatics on both sides of the broad ligament have been observed at surgery after injection of Evans blue into the wall of one uterine horn (R. B. Heap and I. R. Fleet, unpublished observations). Transfer of $\mathrm{PGF}_{2 \alpha}$ by this route is the probable explanation for our earlier results, since Evans blue injected into an ovarian lymphatic has never been detected in uterine lymphatics in the broad ligament. Lignocaine instilled into the vascular pedicle had no consistent inhibitory effect on oxytocin release whether induced by intra-lymphatic or close-arterial infusions of $\mathrm{PGF}_{2 \alpha}$. Electrical stimulation of the ovary at the base of the hilus failed to

Table 3. Effect of insulin-like growth factor-I $\left(7.5 \mathrm{nmol} \mathrm{min}{ }^{-1}\right.$ for $\left.10 \mathrm{~min}\right)$ on ovarian oxytocin release

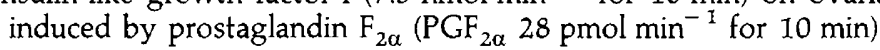

\begin{tabular}{|c|c|c|c|}
\hline \multirow[b]{2}{*}{ Treatment sequence } & \multicolumn{2}{|c|}{ Oxytocin concentration (pg m! $\mathrm{ml}^{-1}$ ) } & \multirow{2}{*}{$\begin{array}{c}\text { Fold-change } \\
\text { (compared with control I) }\end{array}$} \\
\hline & Back-transformed & $\log _{e}$ & \\
\hline Control 1 & 347 & $5.85 \pm 0.66$ & 1.0 \\
\hline $\mathrm{PGF}_{2 \alpha}$ first infusion & 2298 & $7.74 \pm 0.78$ & 6.6 \\
\hline Control 2 & 473 & $6.16 \pm 0.27$ & 1.4 \\
\hline IGF-I & 566 & $6.34 \pm 0.27$ & 1.6 \\
\hline $\mathrm{PGF}_{2 \alpha}$ second infusion & 1808 & $7.50 \pm 0.59^{* *}$ & 5.2 \\
\hline Control 3 & 391 & $5.97 \pm 0.35$ & 1.1 \\
\hline IGF-I & 735 & $6.60 \pm 0.13^{*}$ & 2.1 \\
\hline $\mathrm{PGF}_{2 \alpha}$ third infusion & 1274 & $7.15 \pm 0.55^{* *}$ & 3.7 \\
\hline
\end{tabular}

Compounds were infused close-arterially via a catheter placed cranial to the origin of the ovarian arteries in superovulated non-pregnant sheep 10 days after ovulation. Results are given as the mean concentrations measured in left and right ovarian veins during the infusion period (mean \pm SEM; $n=5$ ).

Statistical analysis of transformed data by paired $t$ test comparing each treatment with the previous control value $\left({ }^{*} P<0.05\right.$, ${ }^{* *} P<0.01$ ) 
stimulate oxytocin release (R. B. Heap, R. G. Dyer and I. R. Fleet, unpublished observations). These findings support the hypothesis that $\mathrm{PGF}_{2 \alpha}$ stimulates ovarian oxytocin locally anddirectly since there was no evidence from these studies for a neurally regulated mechanism.

Ovarian oxytocin release was quantitatively similar whether it was stimulated by intra-lymphatic or close-arterial infusion of $\mathrm{PGF}_{2 \alpha}$. Estimates of the $\mathrm{PGF}_{2 \alpha}$ dose reaching the ovary indicated that the amount transferred across the vascular pedicle from a lymphatic infusion $\left(0.8 \mathrm{pmol}^{-1}\right.$ in $\left.10 \mathrm{~min}\right)$ was similar to that which was infused close-arterially (about $0.7 \mathrm{pmol}$ in $10 \mathrm{~min}$ ). When the close-arterial infusion of $\mathrm{PGF}_{2 \alpha}$ was repeated three times, a tachyphylaxis occurred. This finding implied the depletion of oxytocin reserves in luteal cells or the downregulation of PGF $_{2 \alpha}$ receptors. Luteal content of oxytocin declines gradually after its peak is reached in the mid-luteal phase (Wathes et al., 1986, 1992a). The exponential fall in oxytocin mRNA after days $1-3$ of the oestrous cycle (Fehr et al., 1987; Jones and Flint, 1988; Ivell et al., 1990) suggests that luteal oxytocin synthesis would be low by day 10 , the time of the present experiments. This conclusion is also supported by the observation that the amount of oxytocin released after a third close-arterial $\mathrm{PGF}_{2 \alpha}$ infusion was similar to that achieved after the administration of a different agonist, acetylcholine. The effect of acetylcholine was similar when $\mathrm{PGF}_{2 \alpha}$ had previously been infused into a lymphatic. Since oxytocin is contained within small dense granules located in the large luteal cells (Fields and Fields, 1986; Theodosis et al., 1986), the action of repeated doses of $\mathrm{PGF}_{2 \alpha}$ may be on exocytotic mechanisms or on post-translational processes acting on a preformed precursor within these granules (Camier et al., 1991). Kotwica and Skarzyński (1993) demonstrated a declining response to repeated doses of noradrenaline in cows and suggested that it represented post-translational processing of the prohormone (Fehr et al., 1987) rather than de novo synthesis.

The IGF-I enhancement of ovarian oxytocin release is consistent with studies of dispersed bovine luteal cells after long-term incubation (McArdle and Holtorf, 1989), perfused bovine corpora lutea incubated with high doses (Einspanier et al., 1990), and ovarian IGF-I production in sheep (Wathes et al., 1992b). The dose of IGF-I used in the present study was based on that which produces a physiological vasodilation in the mammary glands of goats in vivo (Prosser et al., 1990). The finding that IGF-I sustains the response to repeated stimulation by $\mathrm{PGF}_{2 \alpha}$ was unexpected. It contrasts with the effect of chronic $\mathrm{PGF}_{2 \alpha}$ treatment in vitro which inhibits IGF-Istimulated oxytocin release (McArdle and Holtorf, 1989). McArdle and Holtorf (1989), however, gave PGF ${ }_{2 \alpha}$ and IGF-I simultaneously, and doses of $\mathrm{PGF}_{2 \alpha}$ were in the micromolarmillimolar range, rather than the nanomolar range used in our experiments. The mechanism by which IGF-I reduces tachyphylaxis is unclear. IGF-I (and insulin) cause a marked increase in oxytocin mRNA in bovine granulosa cell cultures in vitro (Holtorf et al, 1989), but this is an unlikely explanation of our findings since the infusions in vivo were short term (10 min). The effect of $\mathrm{PGF}_{2 \alpha}$ on oxytocin release is mimicked by a protein kinase C activator (McArdle and Holtorf, 1989), so it will be important to ascertain whether IGF-I influences the activity of protein kinase $\mathrm{C}$ in the corpus luteum. An intriguing possibility is that IGF-I and PGF $2 \alpha$ mobilize different forms of secretory granules undergoing separately regulated secretion within one cell (Burgess and Kelly, 1987; Kelly, 1991).

In summary, the present findings in vivo support those in vitro that IGF-I acts on luteal cells to enhance oxytocin release after repeated $\mathrm{PGF}_{2 \alpha}$ treatment. Under the conditions of the present study, IGF-I influenced the corpus luteum in an endocrine manner and not only in the autocrine-paracrine manner, as proposed by Sauerwein et al. (1992).

The authors gratefully acknowledge the excellent support of A. Bucke and M. Richardson.

\section{References}

Abdelgadir SE, Swanson LV, Oldfield JE and Stormshak F (1987) Prostaglandin $\mathrm{F}_{2 \alpha}$-induced release of oxytocin from bovine corpora lutea in vitro Biology of Reproduction 37 550-555

Burgess TL and Kelly RB (1987) Constitutive and regulated secretion of proteins Annual Reviews of Cell Biology 3 243-293

Camier M, Benveniste D, Barré N, Brakch N and Cohen P (1991) Synthesis and processing of pro-oxytocin in bovine corpus luteum and granulosa cells Molecular and Cellular Endocrinology 77 141-147

Einspanier R, Miyamoto A, Schams D, Müller M and Brem G (1990) Tissue concentration, mRNA expression and stimulation of IGF-I in luteal tissue during the oestrous cycle and pregnancy of cows Journal of Reproduction and Fertility $90439-445$

Fehr S, Ivell R, Koll R, Schams D, Fields M and Richter D (1987) Expression of the oxytocin gene in the large cells of the bovine corpus luteum FEBS Letters $21045-50$

Fields MJ and Fields PA (1986) Luteal neurophysin in the nonpregnant cow and ewe: immunocytochemical localisation in membrane-bounded secretory granules of the large luteal cell Endocrinology 118 1723-1725

Flint APF and Sheldrick EL (1982) Ovarian secretion of oxytocin is stimulated by prostaglandin Nature $297587-588$

Heap RB, Fleet IR and Hamon $M$ (1985) Prostaglandin $F_{2 \alpha}$ is transferred from the uterus to the ovary in the sheep by lymphatic and blood vascular pathways journal of Reproduction and Fertility 74 645-656

Heap RB, Fleet IR, Davis AJ, Goode JA, Hamon MH, Walters DE and Flint APF (1989) Neurotransmitters and lymphatic-vascular transfer of prostaglandin $\mathrm{F}_{2 \alpha}$ stimulate ovarian oxytocin output in sheep Journal of Endocrinology $\mathbf{1 2 2}$ $147-159$

Hirst JJ, Rice GE, Jenkin G and Thorburn GD (1986) Secretion of oxytocin and progesterone by ovine corpora lutea in vitro Biology of Reproduction 35 1106-1114

Hirst JJ, Rice GE, Jenkin G and Thorburn GD (1988) Control of oxytocin secretion by ovine corpora lutea: effects of arachidonic acid, phospholipases and prostaglandins Endocrinology 122 774-781

Holtorf A-P, Furuya K, Ivell R and McArdle CA (1989) Oxytocin production and oxytocin messenger ribonucleic acid levels in bovine granulosa cells are regulated by insulin and insulin-like growth factor-I: dependence on developmental status of the ovarian follicle Endocrinology 125 2612-2620

Ivell R, Hunt N, Abend N, Brackman B, Noumeyer D, Lamsa JC and McCracken JA (1990) Structure and ovarian expression of the oxytocin gene in sheep Reproduction, Fertility and Development 2 703-711

Jarry H, Hornschuh R, Pitzel L and Wuttke W (1992) Demonstration of oxytocin release by bovine luteal cells utilizing the reverse hemolytic plaque assay Biology of Reproduction 46 408-413

Jones DSC and Flint APF (1988) Concentrations of oxytocin-neurophysin prohormone mRNA in corpora lutea of sheep during the oestrous cycle and in early pregnancy Journal of Endocrinology 117 409-414

Kelly RB (1991) Secretory granule and synaptic vesicle formation Current Opinion in Cell Biology 3 654-660

Kotwica J and Skarzyński D (1993) Influence of oxytocin removal from the corpus luteum on secretory function and duration of the oestrous cycle in cattle Journal of Reproduction and Fertility 97 411-417

Kotwica J, Skarzynśki D, Jaroszewski J and Kotwica G (1991) Effect of norepinephrine on the release of progesterone and ovarian oxytocin in cattle Animal Reproduction Science 26 179-191 
McArdle CA and Holtorf A-P (1989) Oxytocin and progesterone release from bovine corpus luteal cells in culture: effects of insulin-like growth factor I, insulin, and prostaglandins Endocrinology 124 1278-1286

Prosser CG, Fleet IR, Corps AN, Froesch ER and Heap RB (1990) Increase in milk secretion and mammary blood flow by intra-arterial infusion of insulin-like growth factor-I into the mammary gland of the goat Journal of Endocrinology $126 \quad 437-443$

Sauerwein H, Miyamoto A, Gunther J, Meyer HHD and Schams D (1992) Binding and action of insulin-like growth factors and insulin in bovine luteal tissue during the oestrous cycle Journal of Reproduction and Fertility 96 103-115

Schallenberger E, Schams D, Bullermann B and Walters DL (1984) Pulsatile secretion of gonadotrophins, ovarian steroids and ovarian oxytocin during prostaglandin-induced regression of the corpus luteum in the cow Journal of Reproduction and Fertility 71 493-501

Sheldrick EL and Flint APF (1983) Luteal concentrations of oxytocin decline during early pregnancy in the ewe Journal of Reproduction and Fertility 68 $477-480$

Theodosis DT, Wooding FBP, Sheldrick EL and Flint APF (1986) Ultrastructural localization of oxytocin and neurophysin in the ovine corpus luteum Cell and Tissue Research 243 129-135
Wathes DC and Denning-Kendall PA (1992) Control of synthesis and secretion of ovarian oxytocin in ruminants Journal of Reproduction and Fertility Supplement 45 39-52

Wathes DC, Guldenaar SEF, Swann RW, Webb R, Porter DG and Pickering BT (1986) A combined radioimmunoassay and immunocytochemical study of ovarian oxytocin production during the periovulatory period in the ewe Journal of Reproduction and Fertility $\mathbf{7 8} 167-183$

Wathes DC, Barrett J, Gilbert CL and Yaron Z (1988) Regulation of ovarian oxytocin secretion in domestic ruminants. In Recent Progress in Posterior Pituitary Hormones, pp 227-234 Eds S Yoshida and L Share. Elsevier Science Publishers, Amsterdam

Wathes DC, Denning-Kendall PA, Perks C and Brown D (1992a) Effects of stage of the cycle and estradiol-17 $\beta$ on oxytocin synthesis by ovine granulosa and luteal cells Endocrinology 130 1009-1016

Wathes DC, Davis AJ, Perks C and Denning-Kendall PA (1992b) Regulation of ovarian IGF-1 production in the ewe Journal of Endocrinology 132 (Supplement Abstract 47) 